\title{
FAMÍLIA INTERDITA: TRANSGERACIONALIDADE E SUBJETIVAÇÃO EM TRÊS OBRAS FICCIONAIS
}

\author{
Fabio Scorsolini-Comin ${ }^{\star}$ \\ Manoel Antônio dos Santos ${ }^{\#}$
}

\begin{abstract}
RESUMO. O objetivo deste estudo foi discutir a transmissão psíquica geracional em duas obras do escritor Mia Couto: Antes de nascer $o$ mundo (2009) e Um rio chamado tempo, uma casa chamada terra (2003), e no conto A terceira margem do rio, de Guimarães Rosa (1962). As três obras são narradas pelos filhos e destacam a família como epicentro de uma trama de segredos, interditos e culpabilizações transmitidos de uma geração a outra, possibilitando a compreensão de que o seio familiar permite não apenas a organização das experiências emocionais, mas a também a transmissão de aspectos intersubjetivos aos quais nem sempre as personagens têm acesso. Os segredos ou a não revelação das verdadeiras histórias dos personagens são apenas uma das formas de transmissão, pois, mesmo ocultando o interditado, transfere-se algo, de modo que o não revelar também é uma maneira de destacar o interdito, aquilo que ainda não foi elaborado e que, por conseguinte, não recebeu inscrição psíquica.
\end{abstract}

Palavras-chave: Transmissão psíquica entre gerações; família de origem; Psicologia e literatura.

\section{FAMILY PROHIBITED: TRANSGENERATIONALITY AND SUBJECTIVITY IN THREE FICTIONAL WORKS}

\begin{abstract}
The aim of this study is to discuss the gerational psychic transmission of two works of Mia Couto: Antes de nascer o mundo (2009) and Um rio chamado tempo, uma casa chamada terra (2003) and in the tail of Guimarães Rosa, A terceira margem do rio (1962) (in Portuguese). The three works are narrated by the sons of the families involved in the stories, emphasizing the family as the epicenter of a web of secrets, forbidden and blaming that are transmitted from one generation to another, enabling the understanding that the family environment enables not only the organization of emotional experiences, but the transmission of inter-subjective aspects which they do not always have access. The secrets or no revelation of the true stories are just one form of transmission. The concealment of prohibited contents allowed the transference of something. Failure to disclose is also a way to highlight the interdict, what has not yet been established and that, therefore, has no psychic inscription.
\end{abstract}

Key words: Psychic transmission between generations; family of origin; Psychology and literature.

\section{FAMILIA PROHIBIDA: TRANSGENERACIONALIDAD Y SUBJETIVIDAD EN TRES OBRAS DE FICCIÓN}

RESUMEN. El objetivo es discutir la transmisión psíquica entre las generaciones a partir del análisis de dos obras de Mia Couto (Antes de nascer o mundo y Um rio chamado tempo, uma casa chamada terra, en Portugués) y una de Guimarães Rosa (A terceira margem do rio, en Portugués). Las obras son narradas por los niños, haciendo hincapié en la familia como el epicentro de una red de secretos, prohibidos y culpas, que se transmiten de una generación a otra, lo que permite el entendimiento de que el ambiente familiar permite no sólo la organización de las experiencias emocionales, pero aspectos intersubjetivos de transmisión a la que los personajes no siempre tienen acceso. Los secretos de los personajes son sólo una forma de transmisión, ya que incluso ocultar lo que está prohibido, se termina de descargar algo, así que no revela también una forma de resaltar el entredicho, lo que no ha sido aún establecida y que, por tanto, no tiene inscripción psíquica..

Palabras-clave: Transmisión psíquica entre las generaciones; familia de origen; Psicología y literatura.

Professor Adjunto da Universidade Federal do Triângulo Mineiro (UFTM). Psicólogo, Mestre e Doutor em Psicologia pela Faculdade de Filosofia, Ciências e Letras de Ribeirão Preto da Universidade de São Paulo (FFCLRP-USP).

\# Livre-Docente em Psicoterapia Psicanalítica pela Universidade de São Paulo. Professor Associado do Departamento de Psicologia da Faculdade de Filosofia, Ciências e Letras de Ribeirão Preto da Universidade de São Paulo (FFCLRP-USP). Psicólogo, Mestre e Doutor em Psicologia Clínica pelo Instituto de Psicologia da Universidade de São Paulo (IP-USP). 
A família pode ser compreendida sob diferentes prismas e por diferentes olhares pelos quais pode ser apreendida do ponto de vista teórico-conceitual. Como agência socializadora e instância responsável pela criação e sustentação dos vínculos afetivos, ela permeia a maior parte das produções humanas, estando presente não apenas como objeto de investigação da Psicologia, mas também como uma dimensão que atravessa as artes, as ciências humanas e as ciências da saúde. Desse modo, podemos estudar a família em diferentes cenários e com base em distintas abordagens teórico-metodológicas. Este estudo buscou compreender a organização familiar a partir de sua presença na Literatura, por meio de uma abordagem da psicanálise contemporânea pautada na transmissão psíquica transgeracional (Benghozi, 2010; Kaës, 1998). Como toda escolha metodológica necessária ao fazer científico, optamos por uma determinada descrição de família, o que, obviamente, não invalida nem se sobrepõe a outras possíveis descrições e a outros modos de analisá-la.

Assim, tendo como norte a consideração de que a família de origem é depositária de tensões, medos, segredos, heranças e vínculos que são transmitidos a cada geração, o objetivo deste artigo é discutir o conceito de transgeracionalidade a partir da análise dos arranjos familiares presentes em duas obras do escritor moçambicano Mia Couto: Antes de nascer o mundo (2009) e Um rio chamado tempo, uma casa chamada terra (2003), e no conto de Guimarães Rosa (1962/2005) A terceira margem do rio, que integra o livro Primeiras Estórias, publicado originalmente em 1962.

A escolha dessas obras deve-se ao fato de que retratam o modo velado como os segredos familiares não apenas são transmitidos de uma geração a outra, mas também são (re)velados ou mesmo não solucionados ao longo do crescimento e desenvolvimento de seus narradores protagonistas. Outro ponto que aproxima essas obras, do ponto de vista da construção psicológica da narrativa, é o pressuposto de que, em toda análise do processo de transmissão psíquica geracional, a compreensão passa não apenas pelo modo como aquilo que é transmitido vai sendo incorporado à vida das pessoas, mas também pela maneira como é relatado nos discursos e nomeado pelos membros da família. Nas obras selecionadas, a função de narrador é assumida pelos filhos, imprimindo fortemente a perspectiva de alguém que, de um modo ou de outro, está recebendo as influências de seus antecessores (pais e avós, notadamente), contando a história de suas famílias. É o relato dos filhos que organiza a narrativa do que é aquela família e o que ela transmite ao longo de determinada geração. Também os cenários aproximam as histórias e as personagens das obras em apreço: os dois livros de Mia Couto são ambientados em cenários africanos entrecortados por rios, lendas, tradições e mistérios familiares que ultrapassam as delimitações encerradas pelo ciclo vital - nascer, crescer, casar, ter filhos e morrer. A obra de Guimarães Rosa tem como cenário o rio, delineado em suas três margens, incluindo a dimensão transcendental; portanto são obras que apresentam forte influência da tradição oral.

A aproximação desses autores já vem sendo investigada em outros estudos, notadamente da área de Literatura e Língua Portuguesa (Baseio, 2007; Chagas, 2007; Chaves, 1997; Ferraz, 2010; Rocha, 2000; Silva, 2010; Siqueira, 2009). O que os une passa não apenas pelo estilo de narrativa (Mia Couto assume a influência que recebe de Guimarães Rosa, por exemplo), mas também pela escolha dos cenários e pela influência do ambiente no modo de subjetivação das personagens, além do olhar complexo e percuciente que lançam sobre personagens aparentemente simples e apartados do círculo da urbanização e do progresso material.

A partir dessa consideração, a seleção dos mencionados autores também tem um aporte intertextual, porquanto ambos constroem histórias de forte apelo regional, cercadas de mistérios e interditos, e revelam as dimensões profundas do psiquismo de seus personagens, o que os conecta diretamente às investigações no campo da Psicologia, conforme sugerido em estudos anteriores (Scorsolini-Comin, 2010; Scorsolini-Comin \& Santos, 2010). Tais histórias são permeadas pela aparente confusão entre fantasia e realidade, além de serem viscerais na condução dos dramas que são deflagrados nas famílias que têm suas trajetórias narradas. Apesar da distância temporal, geográfica e estilística que separa as produções literárias desses autores - Guimarães Rosa na década de 1930, no Brasil, e Mia Couto, na década de 1980 em Moçambique -, ambos se valeram da tradição oral em seus textos: em Rosa essa opção mostra o hibridismo cultural brasileiro e em Couto surge como algo que faz parte da organização do cotidiano naquela sociedade (Chagas, 2007).

No que concerne aos enredos que sustentam essas produções ficcionais, no conto A terceira margem do rio lemos que um homem adulto e com filhos decide, sem qualquer motivo aparente, abandonar a família e morar a bordo de uma canoa, isolando-se de qualquer contato com o mundo. Simplesmente um dia ele se despede da família e passa a viver em uma canoa cuidadosamente construída para essa finalidade, 
permanecendo por lá, à deriva, determinado em seu autoexílio, quiçá até o fim dos seus dias. A trama se desenrola a partir da narração do filho já na fase adulta, que vive assombrado pela saudade, pelo sentimento de culpa e pela ausência de notícias do pai.

Em Antes de nascer o mundo, o narrador também é um filho, Mwanito, que convive com os desvarios de um pai viúvo que, após a morte da esposa, decide se enclausurar em uma terra afastada da savana moçambicana, por ele denominada de Jerusalém, levando consigo seus dois filhos, um amigo - seu fiel escudeiro - e um cunhado. O narrador, então, descreve o seu crescimento diante desse acontecimento inusitado e das descobertas que envolvem esse mundo paralelo, habitado por apenas cinco pessoas e muitos segredos. Quando o pai se refugia na chamada Jerusalém, Mwanito ainda era criança, motivo pelo qual não se lembrava da mãe, nem da vida que levava na cidade, ao contrário de seu irmão (Ntunzi), alguns anos mais velho.

Um rio chamado tempo, uma casa chamada terra é uma obra na qual o estudante universitário Marianinho (o narrador da história) volta à ilha de Luar-do-Chão depois de anos de ausência. Seu retorno deve-se ao "aparente" falecimento de seu avô paterno, Dito Mariano, que havia escolhido o neto para comandar a cerimônia de seu velório, em obediência a uma tradição típica daquele lugar. A morte, nesse contexto, era cercada de mistérios e os cerimoniais fúnebres eram praticados com muitos cuidados, tanto para que o morto continuasse sua vida em outro plano, como para que a família não fosse alvo de alguma maldição ou de qualquer prejuízo após a morte do ente querido. Seu retorno o leva a entrar em contato direto com a avó, os tios, o pai e também com diversos segredos familiares que o instituem no centro de uma sentença de vida e morte. Desse modo, ele também se converte em depositário de um poderoso segredo.

$\mathrm{Na}$ abordagem psicanalítica, a família é considerada matriz intersubjetiva e meio de transmissão da vida psíquica entre gerações (Magalhães \& Féres-Carneiro, 2004), uma vez que, "permanentemente afetada pelo acelerado processo de transformação da sociedade, a família continua operando como importante agente de recriação das subjetividades e como suporte para a metabolização desse processo" (p. 254). Essa transmissão intersubjetiva é responsável por promover tanto a vinculação (aproximação entre as pessoas) como a desvinculação, a separação e a ruptura. Embora haja a desvinculação, esta não ocorre de modo completo e definitivo, uma vez que a noção de transgeracionalidade pressupõe uma transmissão que se opera em nível inconsciente e ocorre por e a despeito da deliberação de seus membros.

$\mathrm{Na}$ visão da Kaës (1998), a família seria constituída por um duplo eixo: (a) horizontal, constituído pelas identificações mútuas com seus semelhantes, que geram o sentimento de familiaridade e de continuidade de ações, costumes, crenças, bem como modos de ser e de compreender o mundo; (b) vertical, que abarca a filiação e afiliações que inscrevem o sujeito na sucessão de movimentos de vida e de morte no percurso das gerações (Benghozi, 2010; Magalhães \& Féres-Carneiro, 2004). Em ambos os eixos inexistem garantias acerca do que é e do que pode ser transmitido, nem mesmo das identificações que podem ocorrer. Para refletir sobre essas questões, este estudo se divide em quatro partes, assim designadas: "Uma casa chamada afeto", "Uma família chamada tempo", "Antes de nascer a história" e "O tempo do imponderável".

\section{UMA CASA CHAMADA AFETO}

O estudo da família e dos modelos de relação conjugal vigentes na Pós-Modernidade é fundamental para a compreensão das mudanças ocorridas nas últimas décadas e de suas implicações para o desenvolvimento e amadurecimento dos indivíduos nos contextos familiares atuais (Cicco, Paiva, \& Gomes, 2005). Na contemporaneidade, o outro preenche um vazio que o indivíduo, muitas vezes, sequer reconhece; a relação amorosa se instala, e o indivíduo fragmentado pode viver a ilusão de ser inteiro (Féres-Carneiro, 1998). Gomes e Paiva (2003), ao investigarem as relações tecidas no interior da família e a instituição casamento na perspectiva da mudança do século passado, enfatizam a percepção das transformações que ocorreram na sociedade pósmoderna, de caráter tanto econômico quanto social e psicológico. As referidas autoras argumentam que o casamento é sempre visto dentro da moldura do contexto familiar, no qual a necessidade primordial do casal centrar-se-ia na procriação ("ter filhos"), desconsiderando, de certo modo, as questões da própria conjugalidade.

Para Féres-Carneiro (1998), o desafio de um casal reside, fundamentalmente, no fato de o casamento ou a união ser um palco no qual devem se entrelaçar as individualidades de cada membro, operando-se a construção de um espaço em comum: a conjugalidade. O modelo único que cada par cria é denominado "absoluto do casal", conceito que determina os seus limites, ou seja, concebe o casal como uma entidade composta por duas pessoas e o seu modelo único. Esse 
conceito recebe o nome de identidade conjugal (FéresCarneiro, 1998), que designa aquilo que, na literatura específica, é reconhecido como conjugalidade (Cicco et al., 2005; Diniz-Neto \& Féres-Carneiro, 2005; Menezes \& Lopes, 2007).

Apesar de não ser o foco das obras literárias analisadas no presente estudo, a conjugalidade permeia essas produções ficcionais, tanto pela abordagem de um vínculo conjugal esfacelado (como em A terceira margem do rio), como de um objeto de culpa e negação (Antes de nascer o mundo) ou mesmo de mistério e de interdito (Um rio chamado tempo, uma casa chamada terra). Nos três casos, a conjugalidade dos pais é interrompida pela separação ou pela morte das esposas, que carregam sempre um mistério relacionado à trajetória dos pais, compreendida na perspectiva dos filhos. Não se sabe se e como a esposa de "nosso pai" interferiu na sua decisão de abandonar a família e passar a viver em um barco que flutua à deriva no rio. A mãe simplesmente desiste de convencer o marido a retornar para casa, evanescendo-se na narrativa, assim como a voz dos demais membros (irmãos do narrador). Por outro lado, em Antes de nascer o mundo, o papel da mãe de Mwanito, envolta em mistério, é revelado por uma conhecida da família, que relata, em carta, a via crucis de uma mulher que fora oprimida no lar pelo marido e que, humilhada pelos homens, resolve pôr fim à própria vida. $\mathrm{Na}$ outra obra de Mia Couto, a mãe adotiva do narrador (Mariavilhosa) é cercada pelo mistério da sua esterilidade e de sua morte no rio (também um possível suicídio). Sua verdadeira mãe, no entanto, não chega a construir um laço conjugal com Dito Mariano, pelo relato tornado acessível ao narrador, uma vez que se tratava de uma paixão proibida, que permanece oculta até as últimas páginas do livro.

Segundo Diniz e Féres-Carneiro (2005), ao contrário do que muitos apregoam, a instituição casamento não se encontra em um processo agonizante. Na verdade, as pessoas estão em busca de padrões mais satisfatórios e funcionais de relacionamento amoroso, que propiciem melhores condições para o processo de diferenciação e desenvolvimento psicológico e emocional dos parceiros. De acordo com Féres-Carneiro, Ziviani e Magalhães (2007), diversos autores da vertente psicanalítica, como Eiguer (1984) e Nicollò (1988), assinalam que a conjugalidade, ao mesmo tempo em que reedita o romance familiar, propicia a elaboração das vivências infantis. $\mathrm{O}$ encontro com o parceiro gera a oportunidade de metabolização de experiências emocionais que favorecem o desenvolvimento do psiquismo, entrelaçando passado e presente dentro de um projeto que pressupõe uma perspectiva de futuro a dois.

Desde o momento da concepção o sujeito está marcado pelo olhar dos pais, pelos seus ideais e pelos mitos familiares que se inscrevem no psiquismo e o estruturam. Esses mitos estão fortemente encerrados nas obras de Mia Couto - Marianinho é o fruto que confere concretude à relação adúltera de Dito Mariano com sua cunhada e inicia sua vida como um neto-filho que se vinculará mais à figura de seu avô-pai do que à de seu pai adotivo. No rosto, nos gestos, nos rituais, Marianinho estampa a continuidade perfeita do que fora seu avô-pai, tanto que recebe as chaves da casa em que viviam seus avós quando da morte do velho Mariano. Essa linha de continuidade dinástica evoca o que a Psicanálise argumenta acerca de "sua majestade, o bebê" (Freud, 1914/1996), a saber: que o bebê retoma e encarna o ideal narcísico dos pais e, ao mesmo tempo, alimenta-se desse envoltório narcísico para se constituir como sujeito, de modo que, em um futuro provável, possa constituir novas conjugalidades e novos bebês.

Desse modo, a família, particularmente, os pais, teriam um papel fundamental como intermediários de legados no processo de transmissão psíquica, sustentando as possibilidades de transformação inerentes ao ato de transmitir e permitindo a constituição da subjetivação (Magalhães \& FéresCarneiro, 2007), como se verá a seguir.

\section{UMA FAMÍLIA CHAMADA TEMPO}

De modo geral, a noção de transmissão geracional na Psicanálise é carregada pelo viés da negatividade, ou seja, a maioria dos estudos destaca a polaridade negativa da transmissão, aquilo que jaz oculto, uma vez que deve ser escondido, banido da consciência, em vez de elaborado; transmite-se, preferencialmente, o que "não" contém, o que "não" retém, o que "não" se lembra (Kaës, 1998). Não obstante, de acordo com a leitura de Gomes (2006), transmitir-se-iam também aspectos positivos e adaptativos, como os que amparam e asseguram as continuidades narcísicas, a manutenção dos vínculos intersubjetivos, a tendência à conservação e à preservação das formas de vida, entre outros aspectos transformadores, criativos e de proteção do psiquismo.

Para Ruiz Correa (2003), a transmissão ocorreria de duas maneiras: (a) pelas imagens psíquicas originadas na vida libidinal do sujeito e alimentadas 
pelas experiências dolorosas dos pais ou ascendentes; (b) por meio da censura e dos segredos, que, embora inicialmente não sejam traumáticos, passam a sê-lo pela confluência de diversas situações. Tal processo, para a referida autora, solicitaria um trabalho psíquico inconsciente constante e obrigatório, envolvendo a elaboração e a transformação; no entanto, pode ocorrer tanto a transmissão de aspectos positivos e/ou negativos quanto a interrupção de sua circulação, como observa Benghozi (2010).

A noção de transmissão psíquica geracional se refere à inscrição do sujeito na cadeia simbólica da qual ele é um elo e à qual ao mesmo tempo ele se submete; concerne à estruturação da subjetividade, ao desenvolvimento psíquico daquilo que o sujeito herda, ao seu pertencimento ao grupo familiar e às formações intermediárias que articulam os espaços psíquicos intra e intersubjetivos. Kaës (1998) ressalta que a transmissão geracional implica a precedência do sujeito por mais de um outro e a forma como ele lida com a herança, sendo também pensador e até criador daquilo que foi transmitido. A genealogia mistura tempos e espaços, podendo desencadear repetições, psicopatologias ou elaborações criativas e inovadoras. Assim como a família e o casal, o sujeito tem como tarefa construir, organizar e transformar suas heranças genealógicas, elaborando-as.

Para Bertin e Passos (2003), com o nascimento dos filhos o casal estrutura um grupo familiar, responsável pela escritura dos enredos que serão protagonizados pelas gerações que os sucederem. O desenvolvimento desses enredos pressupõe investimentos recíprocos dos membros do grupo, que continuarão a existir enquanto a criança prover suas expectativas de continuidade. Assim, pertencer a uma família, ou seja, ser considerado suporte de um discurso, oferece ao aparelho psíquico em via de formação um alicerce, uma verdade inicial que sustenta o ingresso do sujeito na história.

No caso de Marianinho, seu nascimento ocorre a partir de um pacto firmado por seu verdadeiro pai (o avô Dito Mariano) e sua mãe adotiva (Mariavilhosa), uma vez que Dito Mariano havia se relacionado com a sua cunhada Admirança, que fora seu grande amor. Vendo a impossibilidade de revelar a traição à sua esposa, o velho Mariano recorre à sua nora Mariavilhosa, que era estéril. Marianinho cresce sem saber quem eram seus verdadeiros pais, sendo, paradoxalmente, a prova da traição do avô e também o seu escolhido como filho predileto para conduzir as cerimônias de seu velório. É o nascimento de Marianinho que apenas faz surgir a possibilidade de revelação do segredo (traição), mas também sela uma mentira para seu pai adotivo, que acreditara que a mulher, por milagre, havia engravidado. Desse modo o narrador personagem é, a um só tempo, o depositário da culpa e da possível redenção de sua família, sendo o único responsável por desvelar o segredo e conduzir o verdadeiro pai à morte, a uma despedida digna e sagrada, conforme os costumes da ilha na qual viviam:

Chamo-o assim de "meu neto" mas é uma fraqueza de expressão. Você é meu filho. Meu maior filho, pois nasceu de um amor sem medida. Por isso, não o escolhi para cerimoniar a minha passagem para a outra margem. Você se escolheu sozinho, a vida escreveu no seu nome o meu próprio nome (Couto, 2003, p. 206).

Marianinho havia recebido do pai-avô não apenas o nome, mas também a possibilidade de ele mesmo continuar e perenizar esse segredo, um segredo que perpassava pela escolha do seu nome. Assim o advertiu o tio Abstinêncio, antes de seu retorno à ilha: "Não esqueça: você recebeu o nome do velho Mariano. Não esqueça." (p. 22). Não lhe cabia a missão de revelar ao seu pai adotivo (na verdade, seu irmão) que a esposa jamais lhe dera um filho, mantendo-o fixado na raiz do significante que o nomeia (abstinência). Não lhe cabia dizer que ele jamais tinha sido, de fato, o seu pai. Em todo o livro, a ligação emocional do pai-avô com o narrador era muito mais forte do que a existente entre este e seu pai adotivo. Sendo assim, nome e segredo são os veículos privilegiados da transmissão psíquica, que atualizam no corpo de Marianinho a curiosa "capacidade" ou "dom" que o livro sugere, ao escrever cartas da autoria de Dito Mariano. Como estava morto, o velho Mariano fazia uso das mãos e da caligrafia do netofilho para se comunicar com este, tal como um médium, inclusive para lhe revelar o mistério acerca de seu nascimento.

$\mathrm{Na}$ mesma obra, o tio mais velho de Marianinho (na verdade, seu irmão mais velho), chamado Abstinêncio, passava a autonomear-se, de tempos em tempos, com os nomes das pessoas que iam falecendo, na tentativa de não apenas reter as características identitárias daqueles que partiam, mas também de incorporar as heranças dessas pessoas em sua cadeia de transmissão. Bertin e Passos (2003) concluem que, no trabalho de transmissão que se opera na sucessão de gerações, cada família transfere sua forma de entender e apreender o mundo externo, assim como de organizar o mundo interno. É a partir desses dispositivos psíquicos que a criança, por meio de suas interpretações, erigirá seu mundo interno, enriquecido 
por suas próprias fantasias. Nessa noção de mundo interno do sujeito é preciso considerar também uma dimensão intragrupal, atual, e uma dimensão histórica constituída a partir de sucessivas gerações e seus legados, dos quais a criança é, por excelência, fiel depositária.

Mwanito, em Antes de nascer o mundo, é um personagem que não se recorda de sua história, de seu nascimento, de sua mãe, de sua casa anterior, de sua família antes da viagem a Jerusalém. A ele é contado muito pouco de sua história, inclusive de sua falecida mãe. Mwanito é um ser imerso no universo paralelo e alternativo criado pelo pai, em uma evidente fuga de seus fantasmas e de seu próprio passado. Se ele não se lembrava de sua trajetória antes de Jerusalém, sua vida se resumia apenas àquele mundo recriado pela loucura paterna, um mundo assombrado pelo pecado, pela morte e pela miséria partilhada por todos os personagens. $\mathrm{O}$ narrador só conhece as quatro pessoas com as quais convive, todos homens, sendo, inclusive, advertido sobre o perigo representado pelas mulheres - e ele sequer se lembrava de como era uma. Assim, seu movimento espontâneo de aproximação com o sexo oposto é impedido pela barreira da culpa que o pai sente - o que, evidentemente, se conecta à história da morte prematura de sua mãe.

Do mesmo modo como vimos na história de Marianinho, os nomes dos personagens de Antes de nascer o mundo revelam uma condição peculiar. Todos os personagens, assim que vão morar em Jerusalém, são rebatizados pelo pai, como se fossem subjugados por uma necessidade de renascer ou de fundar naquele espaço uma existência diferente daquela que antes desfrutavam. A cerimônia do rebatismo comparece na narrativa com a função de afastar maus agouros em torno da nova vida, mas, na concepção do pai de Mwanito, adquire um aspecto de negação do passado. Cumpre destacar que o narrador foi o único que não mudara de nome, uma vez que o pai, Silvestre, o considerava muito jovem para isto:

E fomos convocados um por um. E foi assim: Orlando Macara (nosso querido Tio Madrinho) passou a Tio Aproximado. O meu irmão mais velho, Olindo Ventura, transitou para Ntunzi. O ajudante Ernestinho Sobra foi renomeado como Zacaria Kalashi. E Mateus Ventura, meu atribulado progenitor, se converteu em Silvestre Vitalício. Só eu guardei o mesmo nome: Mwanito.

- Este ainda está nascendo - justificou assim meu pai a permanência do meu nome.

(...) - Somos cinco pessoas, mas há só quatro demónios. A você - apontou para mim -, falta um diabo. Por isso, você nem carece de nenhum nome... basta-lhe assim: mwana, Mwanito (Couto, 2009, p. 38-39).

Ao mudar de nome, mudava-se também a história (ou tentava-se remanejá-la da memória), apagavam-se os rastros do que deveria ser suprimido por obra da amnésia, abrindo espaço para engendrar novas construções e novos nascimentos. Neste sentido, são apagados os nomes que traziam os aspectos de sofrimento vividos pelas personagens. Por outro lado, mesmo com o rebatismo, a história familiar continua atravessando o novo arranjo familiar, constituído pelos cinco homens que se mudam para a chamada Jerusalém, também rebatizada por Silvestre. Tio Aproximado não compreendia bem a intenção de Silvestre com a mudança dos nomes, motivo pelo qual destacava:
Nesse momento, Tio Aproximado interrompeu a cerimónia e pediu a Silvestre que, se o assunto era sério, ao menos ele se lembrasse dos antepassados para nomear os filhos. Sempre tinha sido assim, geração após geração.
- Sossegue os nossos avós, dê o nome deles aos meninos. Proteja esses miúdos.
- Se não há passado, não há antepassados (Couto, 2009, p. 39).

Ao se recusar a fazer a reverência ao passado e prestar homenagem aos ancestrais na cerimônia de rebatismo, Silvestre revela que a possibilidade de uma nova vida, sem as sombras do passado, era mais importante do que reproduzir a tradição de sempre evocar os antepassados. O nome, como elo que sustenta a ligação de uma geração a outra e como veículo de transmissão de histórias e experiências, e também proteção, era transformado, na busca de Silvestre, em algo que pudesse libertar cada membro daquele novo arranjo de todas as agruras que haviam vivido anteriormente. Sem nomes, ou melhor, designados por novos nomes, não havia mais herança a ser honrada, mas uma história que deveria começar para todos ali, em Jerusalém; porém, como destaca Kaës (1998), não há possibilidade de escapar totalmente da herança, não há forma eficaz de negar a história familiar de cada um. Conforme Benghozi (2010), ainda que não possamos escapar das heranças psíquicas, estas poderiam ser reelaboradas a partir dos laços afiliativos, como no casamento e nos relacionamentos interpessoais significativos. Ao mudar o nome, a história mantinha-se intacta. Sendo assim, a morte da mãe de Mwanito, por exemplo, 
ainda que negligenciada pelo pai, é assunto corrente na conversa dos irmãos. Mesmo os esforços do pai para afastar Mwanito de qualquer possibilidade de ligação com a vida anterior - que o leva a não ensinálo a ler e a escrever -, são colocados por terra, haja vista que Ntunzi o ensinara, apoiando-se em cartas de baralho. O irmão mais velho também inoculara em Mwanito uma série de questionamentos e perguntas que só seriam respondidas na vida adulta, quando voltaram à cidade.

A partir das questões de transgeracionalidade, Wagner e Falcke (2001) destacam que a formação do casal - e, consequentemente, de uma nova família - se dá por meio do encontro dos sistemas de crenças das famílias de origem dos cônjuges. Assim, quando as pessoas se casam ou passam a viver em união conjugal, acontece o encaixe entre sistemas míticos de duas estruturas familiares diferentes, que formam um novo sistema, baseado nos sistemas familiares de cada cônjuge. Como pontuado pelas autoras, o casamento ou a união constitui-se, então, em um processo que não é exclusivo do noivo e da noiva, ou do homem e da mulher; ao contrário, "nele estão implicadas fortemente as famílias de origem de cada cônjuge, como transmissoras de um sistema mítico que precisa ser examinado e devidamente considerado na formação do casal" (Wagner \& Falcke, 2001, p. 5). Na compreensão psicanalítica proposta por Benghozi (2010), o casamento ofereceria uma possibilidade de remalhagem dos vínculos filiativos, transmitidos ao nascer. Desse modo, ao encontrar o(a) parceiro(a), os laços poderiam ser remalhados, o que daria margem à elaboração de aspectos desadaptativos ou traumáticos.

A escolha da pessoa amada não é consumada pelo narrador de A terceira margem do rio - o filho escolhe seguir o pai e espreitá-lo a distância. Essa não é a opção de todos os filhos, uma vez que sua irmã havia se casado pouco tempo depois da deliberada reclusão do pai; no entanto o narrador abdica de assumir uma vida amorosa, cuidando para que o pai sempre recebesse alimento e observações detalhadas acerca de sua saúde, que atestavam sua falta de sanidade mental. Embora o filho não assuma, efetivamente, o lugar do pai na canoa, este revela que sua trajetória paterna de isolamento e de contemplação transcendental também é percorrida pelo filho do "lado de cá" da margem, também à espera da resolução de seus próprios conflitos; mas, ao contrário do pai, que transita incessantemente de um extremo a outro do rio, sem ponto de parada, o filho mantém os pés fincados no chão, ainda que na sua linha de fronteira, na margem que delineia o curso d'água. Em um momento raro, a incomunicabilidade é rompida:
Ele me escutou. Ficou em pé. Manejou remo n'água, proava para cá, concordado. E eu tremi, profundo, de repente: porque, antes, ele tinha levantado o braço e feito um saudar de gesto - o primeiro, depois de tamanhos anos decorridos! E eu não podia... Por pavor, arrepiados os cabelos, corri, fugi, me tirei de lá, num procedimento desatinado. Porquanto que ele me pareceu vir: da parte de além. E estou pedindo, pedindo, pedindo um perdão (Rosa, 2005, p. 82).

Ao acompanhar a vida de distanciamento voluntário do pai, o narrador também se isola e se condena ao destino de culpa, fuga e necessidade de revelação, em uma transmissão não tanto de um lugar, como ele aparentemente desejava e o pai aceitara, mas de uma história de contato com os próprios dramas e indagações existenciais - uma busca que é empreendida, no conto, de modo rigorosamente individual e intransferível. Essa reclusão não indicaria apenas uma fuga da realidade ou dos dramas pessoais, mas, precisamente, a necessidade de isolamento e introspecção para articular uma reflexão mais penetrante acerca das suas experiências de vida.

\section{ANTES DE NASCER A HISTÓRIA}

A transmissão psíquica geracional ocorre antes mesmo de o sujeito nascer (Benghozi, 2010; Kaës, 1998; Ruiz Correa, 2003). Quando a mãe está grávida, o filho já começa a ser inscrito na cadeia geradora da transmissão: a ele é dado um nome, uma identidade, é atribuído um jeito de ser (se é calmo, se é agitado, se é responsabilizado pelos "desejos" da mãe), uma condição (se foi desejado, se foi planejado, se nasceu em um momento de crise do casal, se veio após anos de espera do par conjugal, se é uma gestação precoce ou tardia) e também uma missão (integrar o casal, aproximar os tios, ser a primeira neta da família, ser o primeiro filho do casal). Assim, um legado é transmitido àquele que nasce. Como explorado anteriormente, o nome é uma das formas que carregam aquilo que deve ser transmitido, podendo ser o nome de alguém, que nunca é apenas uma repetição nômica, mas uma busca por se transmitir aquilo que se deseja ou se teme. A escolha do nome não é isenta, mas revela os movimentos psíquicos presentes na família que são delegados ao novo membro. O legado da transmissão é corporificado no conto de Guimarães Rosa quando o filho decide assumir o lugar do pai na canoa, na tentativa tanto de se redimir quanto de dar continuidade ao desejo paterno de seguir "rio adentro", isolado do mundo: 
Chamei, umas quantas vezes. E falei, o que me urgia, jurado e declarado, tive que reforçar a voz: - "Pai, o senhor está velho, já fez o seu tanto... Agora, o senhor vem, não carece mais... O senhor vem, e eu, agora mesmo, quando que seja, a ambas vontades, eu tomo o seu lugar, do senhor, na canoa!..." $\mathrm{E}$, assim dizendo, meu coração bateu no compasso do mais certo (Rosa, 2005, p. 8182).

As motivações do filho são enraizadas na culpa que sente pelo fato de o pai estar naquela canoa por um ato deliberado de sua vontade, independentemente de tal reclusão absoluta ser ou não resultante de um gesto tresloucado decorrente da desrazão paterna. De alguma forma, sentia que era sua missão seguir a trajetória do pai e, assim, poupá-lo de tal condição de sofrimento de quem vive entre margens, sem pouso ou porto seguro, à margem da palavra. Não obstante, em nenhum momento essa reclusão do pai é trazida como um sofrimento para si - ao contrário, são os familiares que interpretam tal condição como de extremo sofrimento. Ao se vincularem à figura do "nosso pai", os familiares compartilham sua missão. A saga e a sina do pai não seriam apenas dele, mas também da família, motivo pelo qual o filho se sente "convocado" a continuá-la, embora não consiga ou veja nessa não continuação uma possibilidade de ressignificar a herança que o pai tentara lhe transmitir.

Em Um rio chamado tempo, uma casa chamada terra, não é a culpa subjetiva, e sim, a tradição de enterrar os mortos, que faz com que Marianinho retorne à ilha para conduzir as cerimônias do funeral de seu avô-pai. Ele fora convocado pelo velho Mariano a conduzir esse processo, mesmo sendo jovem e a despeito dos seus tios mais velhos (na verdade, seus irmãos mais velhos). De modo similar, Mwanito era o escolhido por Silvestre, em Antes de nascer o mundo, para permanecer em silêncio com ele ou, em outras palavras, para dividir a carga de culpa pela escolha de fugir de casa e criar a comunidade dos cinco homens de Jerusalém. Aliás, o novo nome autoatribuído, Silvestre Vitalício, patenteia o anseio de perpetuar o que é original, arcaico, selvagem e vital, anterior ao verniz civilizatório.

Um ponto de contato entre as três obras é a separação que se opera entre dois mundos: a realidade cindida entre o que é conhecido e o que se desconhece, entre o lugar que pode ser habitado e o inóspito, inabitável; entre o lugar no qual se vislumbra a possibilidade de redenção e o recinto onde reside o pecado. Esses espaços míticos, em Guimarães Rosa e em Mia Couto, são delimitados pelas margens do veio d'água. No primeiro, o "nosso pai" foge do solo da convivência familiar para abrigar-se na canoa, que segue pelo rio sem certeza do paradeiro, talvez em busca da terceira margem. É o rio que separa a família do pai, o mundo fixo e imóvel com o qual o pai lutava e a vida semovente (ou a experiência transcendental ou transformadora) que ele buscava. Essa cisão revela a própria dificuldade de elaboração das experiências de vida, demarcando fisicamente o território do que pode e do que não pode ser compreendido pelos personagens, assumindo um não dito que não pode ser revelado, mas deve estar submerso, em um modelo que remete ao indizível tratado por Kaës (1998). No conto roseano, é a canoa que constitui sua nova morada, a qual ele não mais deixaria, como narra o filho:

\begin{abstract}
Nosso pai passava ao largo, avistado ou diluso, cruzando na canoa, sem deixar ninguém se chegar à pega ou à fala. (...) nosso pai se desaparecia para a outra banda, aproava a canoa no brejão, de léguas, que há, por entre juncos e mato, e só ele conhecesse, a palmos, a escuridão, daquele. (...) O severo que era, de não se entender, de maneira nenhuma, como ele aguentava. De dia e de noite, com sol ou aguaceiros, calor, sereno, e nas friagens terríveis de meio-do-ano, sem arrumo, só com o chapéu velho na cabeça, por todas as semanas, e meses, e os anos sem fazer conta do se-ir do viver. Não pojava em nenhuma das duas beiras, nem nas ilhas e croas do rio, não pisou mais em chão nem capim (Rosa, 2005, p. 79).
\end{abstract}

$\mathrm{O}$ rio também aparece como um separador margem segregadora - entre a ilha e o "mundo de lá" em Um rio chamado tempo, uma casa chamada terra. A morada, a terra dos personagens, é a ilha. A cidade está situada do outro lado do rio e não é interpretada apenas como um mundo diferente, mas também como um lugar que poderia modificar as pessoas que para lá se deslocassem. As duas dimensões separavam as pessoas da história: Marianinho fora morar na cidade e se afastara da família de origem. Ao retornar à sua casa, era identificado como um estrangeiro, como se sua presença fosse instauradora de uma inevitável maldição para toda a ilha. Na verdade, a ilha trazia à tona a sua própria história - estar perto era ter a possibilidade de revelar segredos, de se descobrir de onde viera, quem eram seu legítimo pai e sua legítima mãe. Marcando esses mundos distintos, que cindem radicalmente os conteúdos recalcados, que são mantidos à margem da palavra e do alcance 
do (sobre)nome próprio, o rio avulta como espaço de redenção, responsável por levar e lavar memórias, apagar registros, mas também por renovar a vida nos sedimentos das dimensões terrenas delimitadas pela dupla margem e pela sombra de uma terceira, que aponta para o transcendente.

Em Antes de nascer o mundo, Jerusalém ocupa uma função similar à da canoa no conto de Guimarães Rosa. É a terra primeva, asilo e exílio, princípio e refúgio de uma nova existência, que permite inaugurar uma linhagem sem traumas, sem fraturas, sem memórias ou desejos. A separação que Silvestre almeja da vida que levava é tão ampla que ele anuncia aos filhos que não existe nada além de Jerusalém. Assim, refunda sua existência e inventa o seu próprio mito de origem: o mundo tinha acabado e eles eram os únicos sobreviventes, nessa história com evidente ressonância bíblica, a evocar a saga de Noé após o dilúvio. Jerusalém era a única terra que havia sido poupada do aniquilamento que se abatera sobre o mundo. Tal como uma sentença apocalíptica que anuncia a alvorada de uma nova vida, tudo que estava atrás e antes de Jerusalém deveria ser apagado e banido e todo o existido, varrido da face da terra. Em uma das passagens do livro, Silvestre ensina os filhos a apagarem as pegadas por onde passavam, para que ninguém os encontrasse ou soubesse que eles estavam ali. O verbo varrer, neste ponto do texto, destaca a tentativa do pai de apagar os vestígios da própria história de família, tamanha a sua dor e revolta, como fica claro no trecho:

(...) O verbo "varrer" só estava certo na língua de nosso pai. Porque era um varrer às avessas: em vez de limpar os caminhos, espalhávamos sobre eles poeiras, galhos, pedras, sementes. $O$ que fazíamos, na realidade? Matávamos, nos nascentes atalhos, a intenção de crescerem e se tornarem estrada. E assim anulávamos o embrião de um qualquer destino.

- Por que razão apagamos a estrada, meu pai?

- Nunca vi estrada que não fosse triste respondeu sem tirar os olhos dos vimes com que trançava um cesto.

E como meu irmão não arredasse, a mostrar que a resposta não o satisfizera, o pai somou argumentos. Nós que víssemos aquilo que a estrada trazia (Couto, 2009, p. 35).

Ao apagar os caminhos por onde haviam passado, Silvestre buscava não deixar pistas sobre o paradeiro seu e de seus dois filhos. É por meio da recuperação das pegadas deixadas nessas trilhas apagadas que os filhos planejam sair de Jerusalém e voltar à casa da família, da qual Mwanito nem se lembrava. A revelação de que Jerusalém, longe de ser a única terra que sobrevivera ao fim do mundo, era um cárcere da família, ocorreu assim que Silvestre ficou doente e necessitou de atendimento médico especializado. Ao ver-se rendido em sua condição de fragilidade física, o pai não consegue impedir que Mwanito redescobrisse sua própria história e desvelasse para si todo o mundo que até então lhe fora sumariamente denegado.

\section{O TEMPO DO IMPONDERÁVEL}

Retomando os objetivos anunciados no início deste estudo - de investigar a transmissão psíquica geracional, o modo como, gradualmente, a família é velada e revelada aos personagens - é um dos pontos de amarração do enredo nas três histórias. Em A terceira margem do rio, o segredo do pai, ou seja, motivo pelo qual ele decidira se enclausurar na canoa, era desconhecido de todos. O segredo permanece não revelado, não é mostrado ao leitor, mas se pode compreender que, qualquer que fosse, não era parte do legado que o filho desejava manter ou ao qual desejava corresponder. Loucura, pagamento de promessa, vergonha, medo, culpa ou qualquer outra possibilidade aventada não permitiram que o filho desse continuidade à saga do pai. A revelação buscada pelo pai continua interditada ao filho e aos demais familiares, mesmo ao final do conto, como herança pétrea, enigmática, indecifrável; mas não é o anseio de desvendamento do mistério que move o filho narrador, e sim, a possibilidade de que ele prossiga com o desvario do pai, em um possível ato de resignação perante o dever de manter vivo o cumprimento de um legado que não se põe em questão. Não obstante, por não ser totalmente compartilhado, tal legado é, inicialmente, recusado pelo filho, e essa recusa acaba por acompanhar também o seu destino e reforçar sua culpa; essa recusa abre a possibilidade de remalhagem do vínculo, rompendo o sofrimento psíquico instaurado pela transmissão. Ao abortar o destino certo, ampliam-se as possibilidades de construção de vinculações mais saudáveis e elaboradas do ponto de vista emocional (Benghozi, 2010).

Para Marianinho, o segredo que ronda as circunstâncias de seu nascimento, a morte trágica da mãe, a dificuldade de se aproximar do pai e o fato de ter sido escolhido para organizar a cerimônia de 
enterro do avô, são revelados em uma carta de Dito Mariano, na qual ele confessa ser seu verdadeiro pai. A entrega ao amor proibido com a cunhada fizera com que ele escondesse Marianinho na cidade, onde o menino crescera sem ter conhecimento de sua real origem - seu pai biológico, na verdade, era o avô, e sua mãe, a tia:

(...) com o tempo o menino cresceu, foi ganhando feições. Admirança definhava só de pensar que esse moço ia revelando a identidade do pai verdadeiro. Ela me suplicou que deixasse esse seu filho sair da ilha. Ele que crescesse fora, longe das vistas. E longe de sua culpa. E o menino foi mandado para a cidade. Lá se fez homem, um homem acertado no sentimento. Esse homem é você, Mariano. Admirança é sua mãe (Couto, 2003, p. 235).

Como fica patente no excerto reproduzido, o narrador era a corporificação da culpa do avô, motivo pelo qual deveria ser mantido fora do alcance do olhar alheio. Ao ver sua vida chegar ao fim, Dito Mariano decide ajustar contas com o passado. Pede a volta do neto-filho e lhe confidencia o segredo, desvelando a rede de parentesco, o que permite que Marianinho reconheça a história de sua origem e os diversos interditos que se haviam colocado ao longo de seu desenvolvimento. Embora sua família de origem continue sendo a mesma, há uma reconfiguração significativa dos papéis, exigindo que o narrador se posicione como órfão e herdeiro do avô-pai, dando prosseguimento ao legado que lhe fora transmitido: de ser o fiel depositário da culpa paterna, herdeiro de uma relação extraconjugal e intrafamiliar que fora reprovada inclusive pela terra, na tradição e na crença local, em um fenômeno que impedia que a agricultura prosperasse e que os mortos fossem enterrados. Ao ser desvelado o segredo, a maldição à qual toda a família estava condenada é desfeita, o que sugere a importância da dissolução do pacto para a constituição das personagens e seus enredos subsequentes.

O mistério que cerca a morte da mãe de Mwanito, em Antes de nascer o mundo, é revelado ao narrador por meio de uma carta redigida por uma de suas conhecidas no enredo. Nela, a portuguesa revela que a mãe do menino não fora morta pelo pai, como suspeitava o irmão mais velho e o próprio leitor é levado a crer, ao longo da narrativa. Na verdade, ela se suicidara após ser brutalmente violentada por vários homens, em um dia no qual resolvera sair de casa para mostrar para si e para Silvestre que poderia ser admirada e desejada por outras pessoas que não apenas o marido. Este, ao saber que a mulher fora estuprada, condena-a pela vergonha que sente, o que leva a mulher a se matar. A dor da desonra e a consequente vergonha que Silvestre sente (e também a culpa por não ter valorizado e amado a esposa como ela desejava) o fazem sair da comunidade e buscar refúgio em Jerusalém, tentando apagar o ocorrido e viver o restante de sua vida com dignidade, afastado das mulheres. Apesar disso, sua história o acompanha, na proposta de uma transmissão inconsciente que ocorre a despeito de sua vontade. Ainda que se mudem os nomes e se apaguem os vestígios, o material psíquico é transmitido, delineando também as histórias de vida dos filhos, em uma não remalhagem dos vínculos (Benghozi, 2010; Kaës, 1998). Os prazeres da carne são trocados por uma vida casta e ascética, já que as mulheres representavam, para Silvestre, um perigo: a tentação do pecado, precursor da danação. Recusar-se a viver em pecado é aceitar a condenação a viver nas sombras daquilo que havia restado de passado - $\mathrm{mm}$ passado incômodo que teimava em se tornar cada vez mais presente.

\section{CONSIDERAÇÕES FINAIS}

As três obras literárias analisadas destacam a família como epicentro de uma trama de segredos, interditos e culpabilizações que são transmitidos de uma geração a outra, possibilitando a compreensão de que o seio familiar permite não apenas a organização das experiências emocionais, mas também a transmissão de aspectos intersubjetivos aos quais nem sempre temos acesso. Os segredos ou a não revelação das verdadeiras histórias dos personagens são apenas uma das formas de transmissão, pois, mesmo ocultando aquilo que se deseja escamotear, acabamos por transferir algo, de modo que o não revelar é uma maneira de destacar o interdito, aquilo que ainda não foi elaborado, portanto não recebeu inscrição psíquica. Esse processo culmina em repetições das histórias de vida de modo inconsciente, o que alerta para a não elaboração de conteúdos, abrindo a possibilidade de que a família encerre em si mesma os vínculos tidos como patológicos e não promotores de desenvolvimento. Para além de um destino comum, a família pode ser compreendida como uma potência para a elaboração e instauração de padrões mais adaptativos de interação e de vinculação. Neste sentido, o olhar da transmissão psíquica 
contribui para problematizarmos e desnaturalizarmos as heranças, para que possamos lançar novas estratégias de ser e estar em família. As remalhagens e desmalhagens permitidas pelas vinculações afiliativas são propostas de interpretação que ultrapassam um destino certo e inequívoco. Investigar esses aspectos da constituição e do desenvolvimento familiar pode contribuir para promover modos mais salutares e adaptativos de vida em família, dando espaço para que as diferentes experiências possam ecoar e ser acolhidas, compartilhadas e elaboradas pelos seus membros, ainda que em um primeiro momento esse processo desperte o sofrimento psíquico e a reavaliação da família de origem e suas histórias.

\section{REFERÊNCIAS}

Baseio, M. A. F. (2007). Entre a magia da voz e a artesania da letra: O sagrado em Manoel de Barros e Mia Couto. Tese de doutorado Não-Publicada, Faculdade de Filosofia, Letras e Ciências Humanas, Universidade de São Paulo, São Paulo.

Benghozi, P. (2010). Malhagem, filiação e afiliação Psicanálise dos vínculos: Casal, família, grupo, instituição e campo social. (E. D. Galery, Trad.). São Paulo: Vetor.

Bertin, I. P., \& Passos, M. C. (2003). A transmissão psíquica em debate: Breve roteiro das concepções psicanalítica e sistêmica. Interações, 8(15), 65-79.

Chagas, S. N. (2007). Nas fronteiras da memória: Guimarães Rosa e Mia Couto, olhares que se cruzam. Tese de doutorado Não-Publicada, Faculdade de Filosofia, Letras e Ciências Humanas da Universidade de São Paulo, São Paulo.

Chaves, R. (1997). Mia Couto: Voz nascida da terra. Novos Estudos, 49, 243-256.

Cicco, M. F., Paiva, M. L., \& Gomes, I. C. (2005). Família e conjugalidade: o sintoma dos filhos frente à imaturidade do casal parental. Psicologia Clínica, $17(2), 53-63$.

Couto, M. (2003). Um rio chamado tempo, uma casa chamada terra. São Paulo: Companhia das Letras.

Couto, M. (2009). Antes de nascer o mundo. São Paulo: Companhia das Letras.

Diniz-Neto, O., \& Féres-Carneiro, T. (2005). Psicoterapia de casal na pós-modernidade: Rupturas e possibilidades. Estudos de Psicologia, 22(2), 133-141.

Eiguer, A. (1984). La thérapie psychoanalitique de couple. Paris: Dunod.

Féres-Carneiro, T. (1998). Casamento contemporâneo: O difícil convívio da individualidade com a conjugalidade. Psicologia: Reflexão e Crítica, 11(2), 379-394.
Féres-Carneiro, T., Ziviani, C., \& Magalhães, A. S. (2007). Questionário sobre a conjugalidade dos pais como instrumento de avaliação. In T. Féres-Carneiro, Família e casal: Saúde, trabalho e modos de vinculação (pp. 251-268). São Paulo: Casa do Psicólogo.

Ferraz, L. M. (2010). A infância e a velhice: Percursos em Manuelzão e Miguilim. Tese de doutorado nãopublicada. Faculdade de Filosofia, Letras e Ciências Humanas, Universidade de São Paulo, São Paulo.

Freud, S. (1996). Sobre o narcisismo: Uma introdução. In S. Freud, Edição Standard Brasileira das Obras Psicológicas Completas de Sigmund Freud. (J. Salomão, Trad.). Rio de Janeiro: Imago. (Original publicado em 1914).

Gomes, I. C. (2006). Os relacionamentos amorosos na contemporaneidade e a psicoterapia psicanalítica. In R. Simon, \& G. K. Levinzon (Org.), Progressos em psicoterapia psicanalítica: Dez anos, uma história (pp. 159-171). São Paulo: Casa do Psicólogo.

Gomes, I. C., \& Paiva, M. L. S. C. (2003). Casamento e família no século XXI: Possibilidade de holding? Psicologia em Estudo, 8(n. especial), 3-9.

Kaës, R. (1998). Os dispositivos psicanalíticos e as incidências da geração. In A. Eiguer (Org.), A transmissão do psiquismo entre gerações (pp. 55-19). São Paulo: Unimarco.

Magalhães, A. S., \& Féres-Carneiro, T. (2004). Transmissão psíquico-geracional na contemporaneidade. Psicologia em Revista, 10(16), 243-255.

Magalhães, A. S., \& Féres-Carneiro, T. (2007). Transmissão psíquica geracional: Um estudo de caso. In T. Féres-Carneiro (Org.), Família e casal: Saúde, trabalho e modos de vinculação (pp. 341-364). São Paulo: Casa do Psicólogo.

Menezes, C. C., \& Lopes, R. C. S. (2007). A transição para o casamento em casais coabitantes e em casais nãocoabitantes. Revista Brasileira de Crescimento $e$ Desenvolvimento Humano, 17(1), 52-63.

Nicollò, A. M. (1988). Soigner à l'intérieur de l'autre: Notes sur la dynamique entre l'individu et la famille. Rome: Mimeo.

Rocha, C. M. V. (2000). Entre margens - Guimarães Rosa e Mia Couto: O encontro possível. In I. L. C. Walty, H. Mari \& M. Z. V. Machado (Orgs.), Veredas de Rosa (pp. 75-89). Belo Horizonte: PUC Minas, CESPUC.

Rosa, J. G. (2005). Primeiras estórias. Rio de Janeiro: Nova Fronteira. (Original publicado em 1962).

Ruiz Correa, O. B. (2003). Transmissão psíquica entre as gerações. Psicologia USP, 14(3), 35-45.

Scorsolini-Comin, F. (2010). A terceira margem do rio: Algumas significações. Revista Querubim, 10, 34-40.

Scorsolini-Comin, F., \& Santos, M. A. (2010). Todos passam pela via crucis: A corporeidade em Clarice Lispector. Psicologia em Estudo, 15(3), 623-632.

Silva, A. C. (2010). A autointertextualidade na obra ficcional de Mia Couto: História, crítica e análise. 
Tese de Doutorado Não-Publicada, Universidade Estadual Paulista Julio de Mesquita Filho, Araraquara.

Siqueira, I. C. P. (2009). A música na prosa de Guimarães Rosa. Tese de Doutorado Não-Publicada. Faculdade de Filosofia, Letras e Ciências Humanas, Universidade de São Paulo, São Paulo.

Recebido em 31/05/2011

Wagner, A., \& Falcke, D. (2001). Satisfação conjugal e

Aceito em 25/06/2012 transgeracionalidade: Uma revisão teórica sobre o tema. Psicologia Clínica, 13(2), 1-15.

Endereço para correspondência:

Fabio Scorsolini-Comin. Instituto de Educação, Letras, Artes, Ciências Humanas e Sociais. Universidade Federal do Triângulo Mineiro. Avenida Getúlio Guaritá, 159, Abadia, CEP: 38025-440, Uberaba-MG, Brasil.E-mail: scorsolini_usp@yahoo.com.br. 